\title{
Word Order or Environment Sharing? A Comparison of Two Semantic Memory Models
}

C. Bellissens and G. Denhière

\section{(2) OpenEdition}

1 Journals

\section{Electronic version}

URL: http://journals.openedition.org/cpl/386

DOI: $10.4000 / \mathrm{cpl} .386$

ISSN: $1379-6100$

\section{Publisher}

Centre PsyCLÉ

\section{Printed version}

Date of publication: 1 December 2002

\section{Electronic reference}

C. Bellissens and G. Denhière, « Word Order or Environment Sharing? A Comparison of Two Semantic Memory Models », Current psychology letters [Online], 2002/3, 9 | 2002, Online since 22 September 2003, connection on 08 September 2020. URL : http://journals.openedition.org/cpl/386 ; DOI : https:// doi.org/10.4000/cpl.386

This text was automatically generated on 8 September 2020.

(C) All rights reserved 
Word Order or Environment Sharing? A Comparison of Two Semantic Memory Models

C. Bellissens and G. Denhière 